\title{
PREVALENCE AND QUALITY OF INFORMED CONSENT FOR PATIENTS UNDERGOING COSMETIC PROCEDURES: A CROSS SECTIONAL STUDY
}

\author{
Mohammed Saud Alsaidan ${ }^{1}$, Aisha H. Abuyassin², Hanin S. Alammar², Ghaiath Hussien ${ }^{3}$
}

\begin{abstract}
Background: Failure of the physician to disclose potential risks and benefits associated with cosmetic procedures is one of the main causes of legal disputes over informed consent. The objective was to assess the prevalence and quality of the informed consent given by patients who undergone cosmetic procedures and its association with post-procedure adverse events. Methods: It was a crosssectional, online, questionnaire-based study conducted during September and October 2020. Eligible adult male and female patients who were attending a governmental dermatology clinic at Al-Kharj city (Saudi Arabia) were invited to join the study. Results: A total of 246 patients were included in the study. Out of 246, $111(45.1 \%)$ patients performed at least one cosmetic procedure before, and $89(80.2 \%)$ of them signed an informed consent. $62(69.7 \%)$ of them signed a consent before the procedure, $17(19.1 \%)$ reported post-procedure adverse events, $16(18.0 \%)$ reported dissatisfactions, and $27(30.3 \%)$ reported either. None of the consent characteristics were significantly associated with higher prevalence of post-procedure adverse events or non-satisfactions. Conclusions: The prevalence and the quality of informed consent before cosmetic procedures are inadequate. Urgent corrections are required to protect the patient's rights and to legally protect the treating physician.
\end{abstract}

Keywords: consent, cosmetics, adverse events, ethical, Saudi Arabia

Prevalencia y calidad del consentimiento informado de los pacientes sometidos a procedimientos estéticos: un estudio transversal

Resumen: Antecedentes: Que el médico no revele los posibles riesgos y beneficios asociados a los procedimientos estéticos es una de las principales causas de las disputas legales sobre el consentimiento informado. El objetivo fue evaluar la prevalencia y la calidad del consentimiento informado dado por los pacientes sometidos a procedimientos estéticos y su asociación con los eventos adversos posteriores al procedimiento. Métodos: Fue un estudio transversal, online, basado en un cuestionario, realizado durante septiembre y octubre de 2020. Se invitó a participar en el estudio a pacientes adultos de ambos sexos que acudían a una clínica dermatológica gubernamental en la ciudad de Al-Kharj (Arabia Saudí). Resultados: Un total de 246 pacientes fueron incluidos en el estudio. De los 246, $111(45,1 \%)$ pacientes se habían sometido al menos a un procedimiento cosmético antes, y 89 (80,2\%) de ellos firmaron un consentimiento informado. $62(69,7 \%)$ de ellos firmaron un consentimiento antes del procedimiento, $17(19,1 \%)$ informaron de acontecimientos adversos posteriores al procedimiento, $16(18,0 \%)$ informaron de insatisfacciones y $27(30,3 \%)$ informaron de cualquiera de los dos. Ninguna de las características del consentimiento se asoció significativamente con una mayor prevalencia de acontecimientos adversos posteriores al procedimiento o insatisfacciones. Conclusiones: La prevalencia y la calidad del consentimiento informado antes de los procedimientos cosméticos son inadecuadas. Se requieren correcciones urgentes para proteger los derechos del paciente y proteger legalmente al médico tratante.

Palabras clave: consentimiento, cosméticos, acontecimientos adversos, ética, Arabia Saudí

Prevalência e Qualidade de Consentimento Informado para Pacientes Submetendo-se a Procedimentos Cosméticos: Um Estudo Transversal

Resumo: Contexto: A falha do médico em comunicar os potenciais riscos e benefícios associados a procedimentos cosméticos é uma das principais causas de disputas legais sobre consentimento informado. $\mathrm{O}$ objetivo foi avaliar a prevalência e qualidade do consentimento informado dado a pacientes que sofreram procedimentos cosméticos e sua associaçáo com eventos adversos pós-procedimento. Métodos: Estudo transversal, online, baseado em questionário, realizado durante setembro e outubro de 2020. Pacientes homens e mulheres, adultos elegíveis, de uma clínica dermatológica governamental da cidade de Al-Kharj (Arábia Saudita) foram convidados a participar do estudo. Resultados: Um total de 246 pacientes foram incluídos no estudo. Dos 246, 111 (45.1\%) pacientes realizaram pelo menos um procedimento cosmético anterior e $89(80.2 \%)$ deles assinaram um consentimento informado. $62(69.7 \%)$ deles assinaram um consentimento antes do procedimento, $17(19.1 \%)$ relataram eventos adversos pós-procedimento, $16(18.0 \%)$ relataram insatisfaçóes e $27(30.3 \%)$ relataram ambos. Nenhuma das características do consentimento foram significativamente associadas com mais alta prevalência de eventos adversos pós-procedimento ou não satisfação. Conclusôes: A prevalência e a qualidade do consentimento informado antes de procedimentos cosméticos são inadequados. Correçôes urgentes são requeridas para proteger os direitos dos pacientes e para legalmente proteger o médico responsável.

Palavras chave: consentimento, cosméticos, eventos adversos, ética, Arábia Saudita

${ }^{1}$ Internal Medicine Department, College of Medicine, Prince Sattam bin Abdulaziz University, Al-Kharj, Saudi Arabia. Correspondence: dr.saidan@hotmail.com

${ }^{2}$ Medical students, Dar Al Uloom University, Riyadh, Saudi Arabia.

${ }^{3}$ College of Public Health and Health Informatics, King Saud Bin Abdulaziz University for Health Sciences, Riyadh, Saudi Arabia. King Abdullah International Medical Research Center, Riyadh, Saudi Arabia. 


\section{Introduction}

There has been global increase in the number of cosmetic procedures performed over the last two decades, mainly due to more availability of minimally invasive procedures $(1,2)$. Several personality, social, and psychological characteristics influence the increasing interest in cosmetic procedures(3). Cosmetic procedures are considered different from traditional surgical procedures as they are done on apparently healthy individuals(4). Nevertheless, medical ethics and regulations are still required to ensure safety and satisfaction of the patient as well as protection of the physician $(5,6)$.

Informed consent is a tool for mutual communication between the physician and patient in which the patient authorizes, permits, or allows the physician to act in a specific way(4). For consent to be informative, the physician must provide the patient with comprehensive information about the nature of the medical condition, the proposed procedure, alternative treatments, risks of adverse events and complications, and the probable degree of improvement $(7,8)$. The informed consent should be written in an understandable language and voluntarily signed by individuals with mental and legal competency to take informed decision $(7,9)$.

In reality, obtaining informed consent for cosmetic procedures is getting challenging due to demanding patient expectations and influences as well as changing legal regulations $(10,11)$. Additionally, cosmetic procedures and plastic surgeries are not without complications(12-14). These complications are currently reflected as increasing number of lawsuits against physicians $(15,16)$. Failure of the physician to disclose potential risks and benefits is the main source of legal disputes over informed consent $(16,17)$. In Saudi Arabia, the consent has been studied in relation to surgical procedures and the quality was poor(18). There is lack of data focusing on consent in cosmetic procedures and post-procedure adverse events. The objective of the current study was to assess the prevalence and quality of informed consent and its association with post-procedure adverse events among patients attending cosmetic clinic. Further this paper could initiate further discus- sion regarding the possible need for modifying the informed consent or being more diligent with the process of informed consent for cosmetic procedures.

\section{Methods}

Setting: The current study was conducted at the dermatology clinic at the University hospital of the Prince Sattam bin Abdulaziz University (PSAU) at Al-Kharj city, Saudi Arabia. The newly established PSAU University hospital is a governmental hospital that provides largely free-healthcare services to patients in the central region of Saudi Arabia, through 36 general and specialized clinics.

Population: The target population included adult male and female patients above 18 years who were attending the dermatology clinic at the PSAU University hospital during September and October 2020.

Design: It was a cross-sectional, online, questionnaire-based study. The study design obtained the required ethical approvals of the ethical committee at the PSAU.

Data collection tool: Internet-based study questionnaire was created in Arabic and English language. It included questions about the demographic characteristics of the patients as well as their experience with last cosmetic procedure, other cosmetic consultations, details of pre-procedure informed consent administration, and details of post-procedure adverse events or nonsatisfactions. Two bilingual (Arabic and English) speakers, translated the questionnaire forth and back and adjusted accordingly. The study questionnaire was reviewed and approved by two experts in dermatology and cosmetic procedures. A pilot study of 15 participants, used to get the feedback of participants before having the final version of the questionnaire.

Recruitment: Patients who were attending the dermatology clinic during September and October 2020 were invited to participate in the study by receiving the link of the study questionnaire. Patients who declined the online informed consent were not allowed to complete the question- 
naire (1.6\%, 4 out of 250 patients). Those who never had experience with cosmetic procedures were asked to prematurely exit the questionnaire (54.9\%, 135 out of 246 patients).

Statistical analysis: The questionnaire data were exported in MS Excel file and then read by SPSS software. All categorical variables were presented as frequencies and percentage while continuous variables were presented as means and standard deviations (SD). Demographic characteristics, experience with previous cosmetic procedures, and informed consent characteristics were compared between those who developed and those who did not develop post-procedure adverse events or non-satisfactions (Tables 1 through 4). Chi-square or Fisher's exact test, as appropriate, were used to examine differences in categorical variables while student $t$-test was used to examine differences in continuous variables. All P-values were two-tailed. P-value $<0.05$ was considered as significant. SPSS software (release 25.0, Armonk, NY: IBM Corp) was used for all statistical analyses.

\section{Results}

Out of 246 patients included in the study, 111 (45.1\%) patients performed at least one cosmetic procedure before (Figure 1). Out of 89 patients who performed a cosmetic procedure and completed the informed consent section, 62 (69.7\%) signed a consent before doing the procedure, 17 (19.1\%) reported post-procedure adverse events, $16(18.0 \%)$ reported dissatisfactions, and 27 (30.3\%) reported either (Figure 1). As shown in Table 1, these dissatisfactions largely included unsatisfactory cosmetic improvement 16 (59.3\%), bruises 7 (25.9\%), and pigmentations 6 (22.2\%). The majority $(77.8 \%)$ of the patients filed a complaint to the administration of the hospital/center with only few $(19.0 \%)$ who were granted free treatment of the complications. Post-complication follow-up was equally done with same and other physicians.

As shown in Table 2, the average age of the respondents was $30.3 \pm 8.4$ years and the vast majority of the respondents were females $(93.3 \%)$. Married (49.4\%) and single (47.2\%) status were similarly represented. The majority of the patients had college $(74.2 \%)$ or postgraduate $(11.2 \%)$ education. Approximately $55.1 \%$ of patients were working, mainly as governmental or private employees. The monthly income was split into approximately three equal groups; one third $<3,000$ Saudi Riyals (SAR), one third 3,000-9,999 SAR, and one third $\geq 10,000$ SAR. There were no significant associations between demographic characteristics and prevalence of post-procedure adverse events or non-satisfactions.

As shown in Table 3, the most frequently performed procedures were laser procedures $(49.4 \%)$, filler injection $(36.0 \%)$, Botox injection $(30.3 \%)$, and surgical procedures under general anesthesia (16.9\%). Approximately two-thirds (65.2\%) of the procedures were done over the last year. Dermatology $(52.8 \%)$ and plastic surgery $(27.0 \%)$ were the most frequent specialty of physician who performed the procedure. The information that were frequently provided to the patients before procedure included the type and purpose of the procedure $(61.8 \%)$, current medical and aesthetic conditions $(43.8 \%)$, and advantages and disadvantages of the procedures $(42.7 \%)$. On the other hand, other treatment options including no treatment $(12.4 \%)$ was the least frequently provided information. More than half $(57.3 \%)$ of the patients believed that the risk of complications was underestimated and more than quarter (27.0\%) believed that the doctor was promoting the procedure. There were no significant associations between the patient's experience with the last cosmetic procedure and the prevalence of post-procedure adverse events or non-satisfactions. However, the belief that the doctor was promoting the procedure tended to be associated with higher prevalence of post-procedure adverse events or non-satisfactions ( $45.8 \%$ versus $24.6 \%$, $\mathrm{p}=0.053)$.

As shown in Table 4, approximately $37.9 \%$ of the patients previously consulted with other physicians on the same cosmetic issue, and the majority $(59.4 \%)$ of these patients were not convinced with physicians because they underestimated the risk of adverse events. The patients who had previous consultation (18.2\% versus 38.9\%, $\mathrm{p}=0.043)$ and who were not convinced $(5.3 \%$ versus $38.5 \%, p=0.029)$ were significantly less likely to develop post-procedure adverse events 
or non-satisfactions. The majority $(83.3 \%)$ of the patients who had filler injection around the eye, nose, or forehead were not told that filling in these areas can rarely cause blindness.

Table 5 shows that the majority of the patients have either fully $(62.3 \%)$ or at least partially $(21.3 \%)$ read the consent before signing. The risk of adverse events in the consent was understandable $(63.9 \%)$ to the participants and the used language was Arabic with or without English translation in the majority of the cases $(82.9 \%)$. Approximately half $(49.2 \%)$ of the patients were provided with a written post-procedure instruction sheet. None of the consent and instruction characteristics were significantly associated with higher prevalence of post-procedure adverse events or non-satisfactions.

\section{Discussion}

Approximately $30 \%$ of the cosmetic procedures were done among patients in the current study were performed without taking informed consent. This is considered a clear deviation from the standard medical practice(5). In addition to breaching patient's rights, it may be used as the basis of suing the physician in case the outcomes are lower than expected(5). Actually, problems with informed consent represent approximately $30 \%$ of legal cases of medical malpractices $(15,19)$. Plastic surgeons performing plastic surgeries or cosmetic procedures are the highest physician group associated with problems with informed consent, including lack of consent(16). Similarly, cosmetic procedures represent $16 \%$ of all legal disputes over informed consent in different medical specialties(17).The lack of informed consent may be related to the elective nature of the treatment(4) and the physician's believe that discussing negative consequences of the procedure with patients may have negative unwanted impact on their decision(20).

The quality of informed consent among the patients in the current study was generally poor, both in content and administration. In the literature, the standard ethical requirements of the informed including the risk of adverse events and complications were met in $12 \%$ to $62 \%$ of the cases(7-9). Additionally, several issues are still required to improve the administration of informed consent. These include giving enough time to read and understand the content. Additionally, all consent should be in Arabic language with or without English translation according to the patient's background. Finally, the patient should be given a copy of the signed consent before leaving the clinic. Similarly, previous studies showed that the quality of informed consent in Saudi Arabia was still poor and required several modifications(18). Essentially, most physicians still adopt a paternalistic attitude while taking informed consent from their patients $(18,20)$.

The current study found that cosmetic procedures ended up with post-procedure adverse events in $19 \%$, and non-satisfactions in $18 \%$ of patients. We could not compare such finding with local data, as there is almost lack of data about adverse events associated with cosmetic procedures in Saudi Arabia(21). Internationally, the rate of adverse events ranged between $<1 \%$ in minimally invasive cosmetic procedures(13) (as in the majority of procedures studied in the current study) and $84 \%$ in traditional plastic surgeries(14).

The findings of the current study did not detect any significant associations between the prevalence, content and administration of the informed consent and post-procedure adverse events or non-satisfactions. It seems that the issues related to lack or poor consent are getting focus only when the procedure ends up with adverse events or non-satisfactions, but without actual association. For example, insufficient or unclear explanation of the risk of post-procedure complications represents $70 \%$ of all allegations made in legal cases related to informed consent, which highly exceed the mere lack or insufficient informed consens $(16,17)$.

Approximately $45 \%$ of the patients in the current study performed at least one cosmetic procedure before. The current prevalence is generally similar to previous studies done in Saudi Arabia(22-24). For example, $42 \%$ to $55 \%$ of Saudi women of different ages interviewed at public places such as shopping malls and Universities had at least one cosmetic procedure $(22,23)$. The most frequently performed procedures in the current study were laser procedures, filler injection, and Botox in- 
jection. This was again very similar to the distribution of procedures reported in different local studies, where laser procedures, filler injection, Botox injection, and chemical peeling were the top procedures performed $(22,23,25)$. The demographic profile of patients undergoing cosmetic procedures in the current study was similar to previous local studies(22-25). They were typically females who were around 30 years old, who are either married or single, and who have a college degree. This profile of patients are likely to be influenced by models of beauty propagated in the social media and TV programs $(26,27)$ and who has a strong wish to improve self-esteem and to pick, attract or keep her partner(23).

The current study is considered the first local study to focus on the prevalence, content and administration of the informed consent for cosmetic procedures and its association with post-procedure adverse events or non-satisfactions. Nevertheless, few limitations are acknowledged. We relied only the participants' views without reviewing the actual consents, however, the study shows the findings of the informed consent process from the patient perspective, which could add to the existing evidence in the literature. Further, one-third of the current patients had their last cosmetic procedure more than a year ago, therefore, recall bias cannot be excluded. Also, being a single center study, results should be generalized with caution outside governmental dermatology clinics. Fur- ther, most of those interested in completing the questionnaire were females, therefore, the results may not be applicable to males or the population in general. However, this study is considered a unique addition to the field of patient consent and the impact of the limitations on the findings is minimal.

In conclusion, approximately $30 \%$ of the cosmetic procedures done among patients attending the dermatology clinic are performed without taking informed consent and ended up with adverse events (19\%) or non-satisfactions (18\%). The quality of informed consent was generally poor in content and administration. There were no significant associations between the prevalence, content and administration of the informed consent and post-procedure adverse events or nonsatisfactions. Multiple changes in the content and administration of informed consent are urgently required to protect the patient's rights and the treating physician

\section{Acknowledgment}

This publication was supported by the Deanship of Scientific Research at Prince Sattam bin Abdulaziz University, Alkharj, Saudi Arabia. 
Prevalence and Quality of Informed Consent for Patients Undergoing Cosmetic Procedures - Mohammed Saud Alsaidan et al.

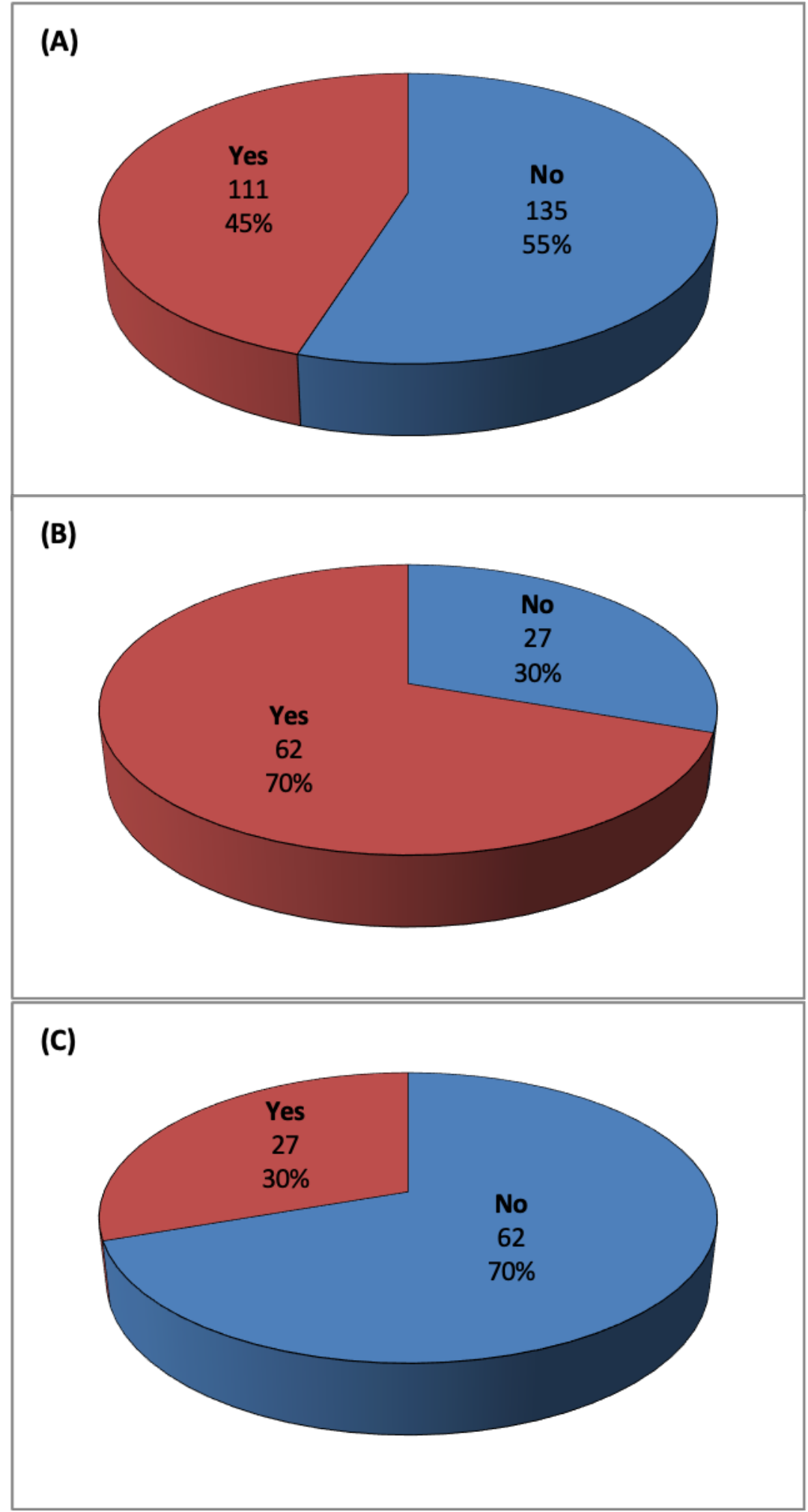

Figure 1: Ever done a cosmetic procedure (A), signing a consent before doing the procedure (B), and the development of post-procedure adverse events or non-satisfaction (C) 
Table 1: Details of post-procedure adverse events or non-satisfactions

\begin{tabular}{|l|r|}
\hline Items & Frequency \\
\hline Type of adverse events or non-satisfactions & $27(100.0 \%)$ \\
\hline Unsatisfactory cosmetic improvement & $16(59.3 \%)$ \\
\hline Adverse events & $17(62.9 \%)$ \\
\hline Bruises & $7(25.9 \%)$ \\
\hline Pigmentations & $6(22.2 \%)$ \\
\hline Slow or no healing & $5(18.5 \%)$ \\
\hline Lumps & $5(18.5 \%)$ \\
\hline Infections/inflammations & $4(14.8 \%)$ \\
\hline Scars & $3(11.1 \%)$ \\
\hline More than expected pain & $3(11.1 \%)$ \\
\hline Burns & $2(7.4 \%)$ \\
\hline Deformity & $1(3.7 \%)$ \\
\hline Vascular blockage & $0(0.0 \%)$ \\
\hline Awareness about the above risks before procedure & $14(51.9 \%)$ \\
\hline No & $13(48.1 \%)$ \\
\hline Yes & \\
\hline Reaction after having adverse events or non-satisfactions & $21(77.8 \%)$ \\
\hline Filed a complaint to the administration of the hospital/center & $1(3.7 \%)$ \\
\hline Filed a legal complaint & $6(22.2 \%)$ \\
\hline None & $17(81.0 \%)$ \\
\hline Results of complaint & $4(19.0 \%)$ \\
\hline No response & $12(44.4 \%)$ \\
\hline Free treatment of complications & $12(44.4 \%)$ \\
\hline Post-complication follow up & $2(7.4 \%)$ \\
\hline With same physician only & $1(3.7 \%)$ \\
\hline With other physician only & \\
\hline With same and other physicians & \\
\hline None & \\
\hline & \\
\hline & \\
\hline & \\
\hline & \\
\hline & \\
\hline & \\
\hline & \\
\hline & \\
\hline & \\
\hline
\end{tabular}


Prevalence and Quality of Informed Consent for Patients Undergoing Cosmetic Procedures - Mohammed Saud Alsaidan et al.

Table 2: Demographic characteristics by the status of post-procedure adverse events or non-satisfactions

\begin{tabular}{|c|c|c|c|c|}
\hline & Total & Adverse even & & P-value \\
\hline & $(\mathrm{N}=89)$ & Yes $(\mathrm{N}=27)$ & Yes $(\mathrm{N}=27)$ & \\
\hline Age (years) & & & & \\
\hline Mean \pm SD & $30.3 \pm 8.4$ & $28.7 \pm 8.3$ & $31.0 \pm 8.5$ & 0.248 \\
\hline$<25$ & $23(25.8 \%)$ & $9(39.1 \%)$ & $14(60.9 \%)$ & 0.547 \\
\hline $25-35$ & $46(51.7 \%)$ & $13(28.3 \%)$ & $33(71.7 \%)$ & \\
\hline$>35$ & $20(22.5 \%)$ & $5(25.0 \%)$ & $15(75.0 \%)$ & \\
\hline Gender & & & & \\
\hline Male & $6(6.7 \%)$ & $4(66.7 \%)$ & $2(33.3 \%)$ & 0.066 \\
\hline Female & $83(93.3 \%)$ & $23(27.7 \%)$ & $60(72.3 \%)$ & \\
\hline Marital status & & & & \\
\hline Married & $44(49.4 \%)$ & $16(36.4 \%)$ & $28(63.6 \%)$ & 0.408 \\
\hline Single & $42(47.2 \%)$ & $11(26.2 \%)$ & $31(73.8 \%)$ & \\
\hline Divorced & $3(3.4 \%)$ & $0(0.0 \%)$ & $3(100.0 \%)$ & \\
\hline Educational level & & & & \\
\hline Less than college & $13(14.6 \%)$ & $1(7.7 \%)$ & $12(92.3 \%)$ & 0.093 \\
\hline College & $66(74.2 \%)$ & $24(36.4 \%)$ & $42(63.6 \%)$ & \\
\hline Post graduate & $10(11.2 \%)$ & $2(20.0 \%)$ & $8(80.0 \%)$ & \\
\hline Working status & & & & \\
\hline No & $40(44.9 \%)$ & $12(30.0 \%)$ & $28(70.0 \%)$ & 0.950 \\
\hline Yes & $49(55.1 \%)$ & $15(30.6 \%)$ & $34(69.4 \%)$ & \\
\hline Occupation & & & & \\
\hline Employee (governmental or private) & $43(48.3 \%)$ & $13(30.2 \%)$ & $30(69.8 \%)$ & 0.757 \\
\hline Self-employed & $6(6.7 \%)$ & $2(33.3 \%)$ & $4(66.7 \%)$ & \\
\hline Student & $22(24.7 \%)$ & $7(31.8 \%)$ & $15(68.2 \%)$ & \\
\hline Retired & $2(2.2 \%)$ & $0(0.0 \%)$ & $2(100.0 \%)$ & \\
\hline Unemployed & $4(4.5 \%)$ & $0(0.0 \%)$ & $4(100.0 \%)$ & \\
\hline Housewife & $12(13.5 \%)$ & $5(41.7 \%)$ & $7(58.3 \%)$ & \\
\hline Monthly income (Saudi Riyals) & & & & \\
\hline$<3,000$ & $31(34.8 \%)$ & $7(22.6 \%)$ & $24(77.4 \%)$ & 0.498 \\
\hline $3,000-9,999$ & $28(31.5 \%)$ & $10(35.7 \%)$ & $18(64.3 \%)$ & \\
\hline$\geq 10,000$ & $30(33.7 \%)$ & $10(33.3 \%)$ & $20(66.7 \%)$ & \\
\hline
\end{tabular}

* Mean \pm standard deviation, otherwise number and percentage 
Table 3: Experience with last cosmetic procedure by the status of post-procedure adverse events or non-satisfactions

\begin{tabular}{|c|c|c|c|c|}
\hline & \multirow{2}{*}{$\begin{array}{l}\text { Total } \\
(\mathrm{N}=89)\end{array}$} & \multicolumn{2}{|c|}{ Adverse events } & \multirow[t]{2}{*}{ P-value } \\
\hline & & Yes $(\mathrm{N}=27)$ & Yes $(\mathrm{N}=27)$ & \\
\hline \multicolumn{5}{|l|}{ Type of last procedure } \\
\hline Laser procedures & $44(49.4 \%)$ & $11(25.0 \%)$ & $33(75.0 \%)$ & 0.279 \\
\hline Filler injection & $32(36.0 \%)$ & $13(40.6 \%)$ & $19(59.4 \%)$ & 0.114 \\
\hline Botox injection & $27(30.3 \%)$ & $5(18.5 \%)$ & $22(81.5 \%)$ & 0.109 \\
\hline Surgical, under general anesthesia & $15(16.9 \%)$ & $7(46.7 \%)$ & $8(53.3 \%)$ & 0.216 \\
\hline Chemical peeling & $8(9.0 \%)$ & $3(37.5 \%)$ & $5(62.5 \%)$ & 0.694 \\
\hline Surgical, under local anesthesia & $7(7.9 \%)$ & $3(42.9 \%)$ & $4(57.1 \%)$ & 0.429 \\
\hline Plasma therapy & $6(6.7 \%)$ & $3(50.0 \%)$ & $3(50.0 \%)$ & 0.362 \\
\hline Thread lifting & $6(6.7 \%)$ & $3(50.0 \%)$ & $3(50.0 \%)$ & 0.362 \\
\hline Body sculpting & $4(4.5 \%)$ & $1(25.0 \%)$ & $3(75.0 \%)$ & $>0.99$ \\
\hline Others & $2(2.2 \%)$ & $0(0.0 \%)$ & $2(100.0 \%)$ & $>0.99$ \\
\hline \multicolumn{5}{|l|}{ Time since last procedure } \\
\hline$<3$ months & $26(29.2 \%)$ & $4(15.4 \%)$ & $22(84.6 \%)$ & 0.134 \\
\hline 3-12 months & $32(36.0 \%)$ & $11(34.4 \%)$ & $21(65.6 \%)$ & \\
\hline$>$ one year & $31(34.8 \%)$ & $12(38.7 \%)$ & $19(61.3 \%)$ & \\
\hline \multicolumn{5}{|l|}{ Specialty of the physician } \\
\hline Dermatology & $47(52.8 \%)$ & $11(23.4 \%)$ & $36(76.6 \%)$ & 0.273 \\
\hline Plastic surgery & $24(27.0 \%)$ & $11(45.8 \%)$ & $13(54.2 \%)$ & \\
\hline Others & $6(6.7 \%)$ & $2(33.3 \%)$ & $4(66.7 \%)$ & \\
\hline Do not know & $12(13.5 \%)$ & $3(25.0 \%)$ & $9(75.0 \%)$ & \\
\hline \multicolumn{5}{|l|}{$\begin{array}{l}\text { Information provided before last } \\
\text { procedure }\end{array}$} \\
\hline Medical and aesthetic conditions & $39(43.8 \%)$ & $12(30.8 \%)$ & $27(69.2 \%)$ & 0.938 \\
\hline Type and objective of procedure & $55(61.8 \%)$ & $15(27.3 \%)$ & $40(72.7 \%)$ & 0.424 \\
\hline $\begin{array}{l}\text { Risk of adverse events or } \\
\text { complications }\end{array}$ & $32(36.0 \%)$ & $10(31.3 \%)$ & $22(68.8 \%)$ & 0.888 \\
\hline Advantages and disadvantages & $38(42.7 \%)$ & $8(21.1 \%)$ & $30(78.9 \%)$ & 0.100 \\
\hline $\begin{array}{l}\text { Other options including no } \\
\text { treatment }\end{array}$ & $11(12.4 \%)$ & $4(36.4 \%)$ & $7(63.6 \%)$ & 0.729 \\
\hline Who is doing the procedure & $27(30.3 \%)$ & $9(33.3 \%)$ & $18(66.7 \%)$ & 0.685 \\
\hline \multicolumn{5}{|l|}{ Experience with last procedure } \\
\hline $\begin{array}{l}\text { The risk of adverse events/ } \\
\text { complications were } \\
\text { underestimated }\end{array}$ & $51(57.3 \%)$ & $18(35.3 \%)$ & $33(64.7 \%)$ & 0.239 \\
\hline $\begin{array}{l}\text { The improvement described was } \\
\text { bigger than noticed later }\end{array}$ & $41(46.1 \%)$ & $14(34.1 \%)$ & $27(65.9 \%)$ & 0.470 \\
\hline $\begin{array}{l}\text { The doctor was promoting the } \\
\text { procedure }\end{array}$ & $24(27.0 \%)$ & $11(45.8 \%)$ & $13(54.2 \%)$ & 0.053 \\
\hline $\begin{array}{l}\text { The doctor told me about } \\
\text { products and machines used in the } \\
\text { procedure and other options }\end{array}$ & $46(51.7 \%)$ & $14(30.4 \%)$ & $32(69.6 \%)$ & 0.983 \\
\hline
\end{tabular}


Prevalence and Quality of Informed Consent for Patients Undergoing Cosmetic Procedures - Mohammed Saud Alsaidan et al.

Table 4: Experience with other consultations by the status of post-procedure adverse events or non-satisfactions

\begin{tabular}{|c|l|l|l|l|}
\hline & \multirow{2}{*}{$\begin{array}{l}\text { Total } \\
(\mathrm{N}=89)\end{array}$} & \multicolumn{2}{l|}{ Adverse events } & \multirow{2}{*}{ P-value } \\
\cline { 2 - 4 } & & & & \\
\hline $\begin{array}{l}\text { Did you previously consult with } \\
\text { other physicians on the same } \\
\text { cosmetic issue? }\end{array}$ & & & & \\
\hline No & $54(62.1 \%)$ & $21(38.9 \%)$ & $33(61.1 \%)$ & 0.043 \\
\hline Yes & $33(37.9 \%)$ & $6(18.2 \%)$ & $27(81.8 \%)$ & \\
\hline $\begin{array}{l}\text { Did you notice differences } \\
\text { between physicians in explaining } \\
\text { the risk of adverse events? }\end{array}$ & & & & \\
\hline No & $15(46.9 \%)$ & $1(6.7 \%)$ & $14(93.3 \%)$ & 0.178 \\
\hline Yes & $17(53.1 \%)$ & $5(29.4 \%)$ & $12(70.6 \%)$ & \\
\hline $\begin{array}{l}\text { Do you think detailed } \\
\text { explanation of the risk of } \\
\text { adverse events can change your } \\
\text { willingness to do the procedure? }\end{array}$ & $13(40.6 \%)$ & $2(15.4 \%)$ & $11(84.6 \%)$ & $>0.99$ \\
\hline No & $19(59.4 \%)$ & $4(21.1 \%)$ & $15(78.9 \%)$ & \\
\hline Yes & & & & \\
\hline $\begin{array}{l}\text { Were you more convinced with } \\
\text { the physician who underestimated } \\
\text { the risk of adverse events? }\end{array}$ & & & & \\
\hline No & $19(59.4 \%)$ & $1(5.3 \%)$ & $18(94.7 \%)$ & 0.029 \\
\hline Yes & $13(40.6 \%)$ & $5(38.5 \%)$ & $8(61.5 \%)$ & \\
\hline $\begin{array}{l}\text { Did you have filler injection } \\
\text { around the eye, nose, or forehead }\end{array}$ & $65(73.0 \%)$ & $19(29.2 \%)$ & $46(70.8 \%)$ & 0.709 \\
\hline $\begin{array}{l}\text { No } \\
\text { Yes }\end{array}$ & $24(27.0 \%)$ & $8(33.3 \%)$ & $16(66.7 \%)$ & \\
\hline $\begin{array}{l}\text { Were you aware that filling } \\
\text { in these areas can rarely cause } \\
\text { blindness }\end{array}$ & $20(83.3 \%)$ & $7(35.0 \%)$ & $13(65.0 \%)$ & \\
\hline No & $4(16.7 \%)$ & $1(25.0 \%)$ & $3(75.0 \%)$ & \\
\hline Yes & & & & \\
\hline
\end{tabular}


Table 5: Informed consent by the status of post-procedure adverse events or non-satisfactions

\begin{tabular}{|c|c|c|c|c|}
\hline & \multirow{2}{*}{$\begin{array}{l}\text { Total } \\
(\mathrm{N}=89)\end{array}$} & \multicolumn{2}{|c|}{ Adverse events } & \multirow[t]{2}{*}{ P-value } \\
\hline & & Yes $(\mathrm{N}=27)$ & No $(\mathrm{N}=62)$ & \\
\hline \multicolumn{5}{|l|}{$\begin{array}{l}\text { Did you sign a procedure consent } \\
\text { form before doing procedure? }\end{array}$} \\
\hline No & $27(30.3 \%)$ & $9(33.3 \%)$ & $18(66.7 \%)$ & 0.685 \\
\hline Yes & $62(69.7 \%)$ & $18(29.0 \%)$ & $44(71.0 \%)$ & \\
\hline \multicolumn{5}{|l|}{$\begin{array}{l}\text { Did you read the details of the } \\
\text { procedure consent form before } \\
\text { signing? }\end{array}$} \\
\hline Fully read & $38(62.3 \%)$ & $13(34.2 \%)$ & $25(65.8 \%)$ & 0.619 \\
\hline Partially read & $13(21.3 \%)$ & $3(23.1 \%)$ & $10(76.9 \%)$ & \\
\hline Only signed & $10(16.4 \%)$ & $2(20.0 \%)$ & $8(80.0 \%)$ & \\
\hline \multicolumn{5}{|l|}{$\begin{array}{l}\text { Did you leave unfilled spaces in } \\
\text { the procedure consent form? }\end{array}$} \\
\hline No & $26(42.6 \%)$ & $6(23.1 \%)$ & $20(76.9 \%)$ & 0.344 \\
\hline Yes & $8(13.1 \%)$ & $4(50.0 \%)$ & $4(50.0 \%)$ & \\
\hline Do not know & $27(44.3 \%)$ & $8(29.6 \%)$ & $19(70.4 \%)$ & \\
\hline \multicolumn{5}{|l|}{$\begin{array}{l}\text { Did you feel the doctor or nurse } \\
\text { want you to quickly sign the } \\
\text { procedure consent form? }\end{array}$} \\
\hline No & $40(65.6 \%)$ & $9(22.5 \%)$ & $31(77.5 \%)$ & 0.261 \\
\hline Yes & $12(19.7 \%)$ & $5(41.7 \%)$ & $7(58.3 \%)$ & \\
\hline Do not know & $9(14.8 \%)$ & $4(44.4 \%)$ & $5(55.6 \%)$ & \\
\hline \multicolumn{5}{|l|}{$\begin{array}{l}\text { Was the language of risk of adverse } \\
\text { events in the procedure consent } \\
\text { form understandable? }\end{array}$} \\
\hline No & $8(13.1 \%)$ & $4(50.0 \%)$ & $4(50.0 \%)$ & 0.120 \\
\hline Yes & $39(63.9 \%)$ & $8(20.5 \%)$ & $31(79.5 \%)$ & \\
\hline Do not know & $14(23.0 \%)$ & $6(42.9 \%)$ & $8(57.1 \%)$ & \\
\hline \multicolumn{5}{|l|}{$\begin{array}{l}\text { What was the language of the } \\
\text { procedure consent form? }\end{array}$} \\
\hline Arabic only & $27(44.3 \%)$ & $8(29.6 \%)$ & $19(70.4 \%)$ & 0.487 \\
\hline English only & $8(13.1 \%)$ & $1(12.5 \%)$ & $7(87.5 \%)$ & \\
\hline Both Arabic and English & $26(42.6 \%)$ & $9(34.6 \%)$ & $17(65.4 \%)$ & \\
\hline \multicolumn{5}{|l|}{$\begin{array}{l}\text { Did you get a copy of the procedure } \\
\text { consent form after signing? }\end{array}$} \\
\hline No & $49(80.3 \%)$ & $15(30.6 \%)$ & $34(69.4 \%)$ & $>0.99$ \\
\hline Yes & $12(19.7 \%)$ & $3(25.0 \%)$ & $9(75.0 \%)$ & \\
\hline \multicolumn{5}{|l|}{$\begin{array}{l}\text { Did you get a written instruction } \\
\text { sheet for what is allowed and non- } \\
\text { allowed after procedure? }\end{array}$} \\
\hline No & $31(50.8 \%)$ & $8(25.8 \%)$ & $23(74.2 \%)$ & 0.519 \\
\hline Yes & $30(49.2 \%)$ & $10(33.3 \%)$ & $20(66.7 \%)$ & \\
\hline
\end{tabular}


Prevalence and Quality of Informed Consent for Patients Undergoing Cosmetic Procedures - Mohammed Saud Alsaidan et al.

\section{References}

1. International Society of Aesthetic Plastic Surgery. ISAPS international survey on aesthetic/cosmetic procedures performed in 2018. URL: https:/www.isaps.org/wp-content/uploads/2020/10/ISAPS-Global-Survey-Results-2018-1.pdf (Last accessed October, 20, 2020). 2019.

2. American Society of Plastic Surgeons. Plastic Surgery Statistics Report, 2019. URL: https://www.plasticsurgery.org/documents/ News/Statistics/2019/plastic-surgery-statistics-full-report-2019.pdf (Last accessed October, 20, 2020). 2020.

3. Milothridis P, Pavlidis L, Haidich A-B, Panagopoulou E. A systematic review of the factors predicting the interest in cosmetic plastic surgery. Indian J Plast Surg 2016; 49(3): 397-402.

4. Nejadsarvari N, Ebrahimi A. Different aspects of informed consent in aesthetic surgeries. World J Plast Surg 2014; 3(2): 81-86.

5. Satyanarayana Rao KH. Informed consent: an ethical obligation or legal compulsion? J Cutan Aesthet Surg 2008; 1(1): 33-35.

6. Morselli PG, Lippi A, Giorgini FA, Fabbri E, Pinto V. Informed consent in plastic surgery, evaluation of its effectiveness for mutual satisfaction of patient and doctor: Comparison of methods. J Plast Reconstr Aesthet Surg 2019; 72(11): 1847-1855.

7. Kapoor L. Informed consent in aesthetic surgery. J Cutan Aesthet Surg 2015; 8(3): 173-174.

8. Anderson O, Wearne I. Informed consent for elective surgery - What is best practice? Journal of the Royal Society of Medicine 2007; 100: 97-100.

9. Holden ACL, Stewart C. Limits to consent in cosmetic interventions: an update. Intern Med J 2019; 49(8): 1022-1025.

10. Barone M, Cogliandro A, La Monaca G, Tambone V, Persichetti P. Cognitive investigation study of patients admitted for cosmetic surgery: information, expectations, and consent for treatment. Arch Plast Surg 2015; 42(1): 46-51.

11. Shah AK. Newer implications of medico-legal and consent issues in plastic surgery. Indian J Plast Surg 2014; 47(2): $199-202$.

12. Vanaman M, Fabi SG, Carruthers J. Complications in the Cosmetic Dermatology Patient: A Review and Our Experience (Part 2). Dermatol Surg 2016; 42(1): 12-20.

13. Alam M, Kakar R, Nodzenski M, Ibrahim O, Disphanurat W, Bolotin D, et al. Multicenter prospective cohort study of the incidence of adverse events associated with cosmetic dermatologic procedures: lasers, energy devices, and injectable neurotoxins and fillers. JAMA Dermatol 2015; 151(3): 271-277.

14. Morzycki AD, Hudson AS, Samargandi OA, Bezuhly M, Williams JG. Reporting Adverse Events in Plastic Surgery: A Systematic Review of Randomized Controlled Trials. Plast Reconstr Surg 2019; 143(1): 199e-208e.

15. Park BY, Kwon J, Kang SR, Hong SE. Informed Consent as a Litigation Strategy in the Field of Aesthetic Surgery: An Analysis Based on Court Precedents. Arch Plast Surg 2016; 43(5): 402-410.

16. Gogos AJ, Clark RB, Bismark MM, Gruen RL, Studdert DM. When informed consent goes poorly: a descriptive study of medical negligence claims and patient complaints. Med J Aust 2011; 195(6): 340-344.

17. Bismark MM, Gogos AJ, McCombe D, Clark RB, Gruen RL, Studdert DM. Legal disputes over informed consent for cosmetic procedures: a descriptive study of negligence claims and complaints in Australia. J Plast Reconstr Aesthet Surg 2012; 65(11): 1506-1512.

18. Abolfotouh MA, Adlan AA. Quality of informed consent for invasive procedures in central Saudi Arabia. Int J Gen Med 2012; 5: 269-275.

19. Abbott RL. Medical malpractice predictors and risk factors for ophthalmologists performing LASIK and PRK surgery. Trans Am Ophthalmol Soc 2003; 101: 239-274.

20. Jamjoom BA, Jamjoom AA, Sharab M, Jamjoom AB. Attitudes towards informed consent: a comparison between surgeons working in saudi arabia and the United kingdom. Oman Med J 2011; 26(1): 29-33.

21. Shoughy SS. Visual loss following cosmetic facial filler injection. Arq Bras Oftalmol 2019; 82(6): 511-513.

22. Almasri RA, Alomawi MA, Fahad M, Alhabshan HA, Alosaimi MS. Number of cosmetic procedures among women in Saudi community. International Journal of Medicine in Developing Countries 2019; 3(11): 920-925.

23. Al-Natour SH. Motives for cosmetic procedures in Saudi women. Skinmed 2014; 12(3): 150-153.

24. Morait SA, Abuhaimed MA, Alharbi MS, Almohsen BE, Alturki AT, Alarbash AA. Attitudes and acceptance of the Saudi population toward cosmetic surgeries in Riyadh, Saudi Arabia. J Family Med Prim Care 2019; 8(5): 1685-1690.

25. Alharethy SE. Trends and demographic characteristics of Saudi cosmetic surgery patients. Saudi Med J 2017; 38(7): 738-741.

26. Aldosari BF, Alkarzae M, Almuhaya R, Aldhahri R, Alrashid H. Effect of Media on Facial Plastic Surgery in Saudi Arabia. Cureus 2019; 11(11): e6232.

27. Almuhaya R, Alarfaj A, Alturki L, Al Tawil L, Alrajeh A, Alkarzae M. The Reasons Behind the Trending of Facial Plastic Surgery in Saudi Arabia. Sch J Oto 2019; 1(5): 93-98.

Received: December 1, 2020

Accepted: December 18, 2020 